Acta Theriologica 37 (1 - 2): 91 - 101, 1992.

PL ISSN $0001-7051$

\title{
Home ranges of sympatric soricine shrews in Hokkaido, Japan
}

\author{
Satoshi OHDACHI*
}

\begin{abstract}
Ohdachi S. 1992. Home ranges of sympatric soricine shrews in Hokkaido, Japan. Acta theriol. 37: $91-101$.

Home ranges of sympatric shrews, Sorex unguiculatus Dobson, 1890 S. gracillimus Thomas, 1907 and $S$. caecutiens Thomas, 1907 were studied by a mark-recepture method during the non-snow covered seasons in northern Hokkaido, 1988 and 1989. Home range size of $S$. unguiculatus, the largest species ( $15.1 \mathrm{~g}$ for adult males), was not significantly different from that of $S$. gracillimus, the smallest species $(4.4 \mathrm{~g}$ for adult males). Both $S$. unguiculatus and $S$. gracillimus had more exclusive home ranges within species than between species. Tolerance of home range overlap may be related to the reduction of dietary overlap. No reliable information of home range for $S$. caecutiens was obtained in this study.

Institute of Applied Zoology, Faculty of Agriculture, Hokkaido University, Sapporo, Hokkaido, Japan 060

Key words: Sorex, home range, mark-recapture study, Hokkaido
\end{abstract}

\section{Introduction}

The influence of interspecific competition in shaping guild structure can be reflected in the partitioning of resources between species, including differences in use of space (Hill and Lein 1989, Murray 1971, Schoener 1968, 1986; Wiens 1989), although some authors insist that experiments be needed to establish its importance (Connell 1983, Schoener 1983a). Further, comparison of interspecific relationships of resource use between different guilds may yield instructive insights into the influence of interspecific competition on guild structure.

Eighty six species of soricine shrews (subfamily Soricinae) are wide-spread throughout the temperature and boreal zones in the northern hemisphere (Macdonald 1984), where they occur in multi-species assemblages or guilds. In Europe, Siberia, and North America, the ecology of shrews is well studied in comparison to Asia, and interspecific relationships of spatial and food resource utilization are known for some species. However, in Hokkaido, northern Japan, there have been only a few ecological studies on shrews (e.g. Abe 1968, Inoue 1988, 1989), although there are four species of Sorex (S. unguiculatus Dobson, 1980;

*Present address: Zoological Section, Institute of Low Temperature Science, Hokkaido University, Sapporo, Japan 060 
S. caecutiens Thomas, $1907 ;$ S. gracillimus Thomas, 1907 ; and S. minutissimus Thomas, 1906) and Crosidura dsinezumi Temminck, 1844 (Abe 1967) and the former three species of Sorex are the most abundant ones in the small mammalian fauna (pers. obs.).

In this paper, I examine home range size and overlap within and between species for two sympatric Sorex shrews in Hokkaido (S. unguiculatus and S. gracillimus) and give supplemental information of home range for S. caecutiens. Then I relative home range overlap and size to food habits and discuss how the shrews partition space, comparing it with some other soricid guilds.

\section{Materials and methods}

\section{Study area}

The survey was carried out in Horonobe $\left(45^{\circ} \mathrm{N}, 142^{\circ} \mathrm{E}\right)$, northern Hokkaido, from September to November 1988, and from April to October 1989. Temperatures in the study area range approximately from -35 to $35^{\circ} \mathrm{C}$ during a year, and the annual average temperature is $5^{\circ} \mathrm{C}$ (data from the office of Teshio Experimental Forest, Hokkaido University). Mean annual precipitation is 1,200 $\mathrm{mm}$. Snow depth is approximately $1,000 \mathrm{~mm}$ in lowlands (ca. $40-100 \mathrm{~m}$ altitude) and 2,000 $\mathrm{mm}$ in high mountainous areas (ca. $100-500 \mathrm{~m}$ alt.). Snow cover usually exists from early December to the middle of April in lowlands, and from late November to early May in the mountainous areas.

The main native vegetation types are Picea glehnii forest in the serpentine zones and the mixed forests of conifers (Picea jesoensis and Abies sachaliensis) and deciduous trees (such as Quercus mongolica, Tilia japonica, Betula spp., Acer spp., and Ulmus spp.). The forest floors are covered with dense Sasa bamboo (Sasa kurilensis). Most of the plain areas and some of the hills are cultivated into

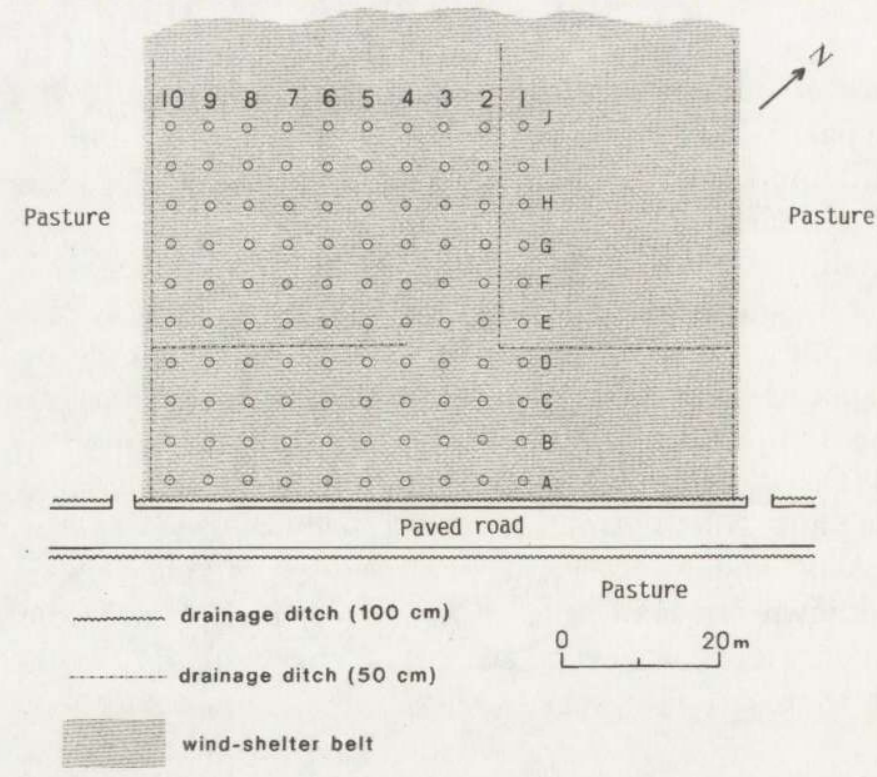

Fig. 1. Permanent trapping grid of a mark-recapture study of shrew species in northern Hokkaido, Japan, 1988 and 1989. Small circles are the fixed points of the trap grid. 
pastures and ranches, and wind-shelter belts of Fraxinus mandshrurica are constructed among them. The forest floor of the wind-shelter belt is covered with dense Sasa senanensis, sparse tall herbs such as Polygonum sachaliense and Senecio cannabifolius, and ferns (Pteridium aqurinum).

In addition to the three species of Sorex examined in this study, $S$. minutissimus also occurs in the study area but is seldom caught (Ohdachi 1990, Ohdachi and Maekawa 1990a). Four species of rodents (Clethrionomys rufocanus bedfordiae, C. rutilus, Apodemus argenteus, and A. speciosus) coexist with the shrews; however, population density of each rodent species is lower than that of $S$. unguiculatus or S. gracillimus (Ohdachi 1990).

\section{Trapping procedure}

To investigate the home ranges of shrews, a mark-recapture program was carried out in a windshelter belt once a month. One hundred polyethylene pit-fall traps $(16 \mathrm{~cm}$ diameter at the opening and $20 \mathrm{~cm}$ depth) were set in a permanent 10 - by 10 -grid at $5 \mathrm{~m}$ intervals (Fig. 1). However, in November 1988 and on 28 September 1989, only 50 traps (from A-1 to E-10; Fig. 1) were used due to snow and heavy rains, respectively. The locations of $10-20$ traps arbitrarily chosen from the 100 traps were moved within a $1.5 \mathrm{~m}$ radius of the fixed points of the grid before daily surveys in order that shrews did not habituate traps. There are small ditches across the trap grid, but they contain no water except just after snow melt in spring. The trap grid was not enclosed by barriers, although a paved road ran along trapline 'A' and pasture expanded outside line ' 10 ' (Fig. 1).

Census was conducted for $3-5$ (usually 5 ) days each month, but a census was interrupted when it rained heavily. Traps were checked four or five times a night at 2 hour intervals from 16 September 1988 to 26 July 1989 and at 1.5 hour intervals from 27 July to 26 October 1989. Traps were opened 1.5 or two hours prior to the first check of each daily survey, and were first checked around sunset (2000 h from April to July, $1930 \mathrm{~h}$ in August, $1830 \mathrm{~h}$ in September, and $1800 \mathrm{~h}$ in October and Novemter). The final checking of traps was begun around midnight or early morning $(2300-0230$ h), and wood plates or twigs were put into all traps so that shrews could escape from the traps. Irregulerly, a single census was carried by day $(1200-1800 \mathrm{~h})$ on 24 October 1988 . To reduce mortality from starvation, small amounts of minced meat (chicken or pork), dried herring, kamaboko (a kind of fish sausage), or frozen silk worm larvae were placed in the traps.

Capure point, time, species, identification number, age (young or overwintered), sex, and body mass were recorded for each specimen captured. Toe-clipping was used to identify individuals; one digit from a forefoot and one from a hindfoot were cut off. Age determination was based on body mass and pelıge (Abe 1958). For Sorex in Hokkaido, except $S$. minutissimus, no young individuals become mature untill the next spring and all overwintered individuals are mature (Abe 1968, Inoue 1989, Ohdach and Maekawa 1990b). Therefore, for overwintered individuals, males were easily determined by descended testes and females by enlarged mammae. I did not determine the sexes of young individuals, except ones which were accidentelly killed in traps and dissected later.

\section{Home range calculation}

Hone range size of individuals was estimated as the maximum observed length between capture points, and as the area determined by the convex polygon (minimum area) method (Stickel 1954). Home ringe size was calculated for 'residents' which had more than three different capture points, with no more than one of these in traps in row ' 1 ' or column ' $J$ ' (Fig. 1); I assumed that shrews did not move beyond traps in row ' 10 ' and column 'A' since there was a wide paved road or pasture outside these trap ines. I defined 'residents' as shrews which were captured in the trap grid in more than two moithly surveys. I used all capture points during the whole study period for the estimation of the hone range size. This procedure of home range estimation is appropriate at least for $S$. unguiculatus, because the home range of the residential individuals do not change largely between months (Incue 1989). 
Home range overlap (maximum overlap percentage) of an individual was calculated by the formula: $100 \mathrm{X}(0 / H)$, where $H$ was the area of home range for an individual of interest, and 0 was the maximum overlapping area with co-occuring individual(s) over the whole study period.

\section{Results}

The total numbers of captured individuals was 37 for $S$. unguiculatus, 28 for $S$. gracillimus, and 10 for $S$. caecutiens over the whole study period (including those found dead in traps). The total numbers of residents was 10 for $S$. unguiculatus, 5 for $S$. gracillimus, and one for $S$. caecutiens. One male $S$. unguiculatus (No. 004) was the only individual captured in both 1988 and 1989. It was first captured on 16 September 1988, and last captured on 28 April 1989.

The accidental death rate in traps was highest in S. gracillimus. The death rate was $2.7 \%$ ( 2 dead shrews found in traps / 74 total capture times) for $S$. unguiculatus, $8.3 \%$ (1/12) for S. caecutiens, and $13.3 \%$ (6/45) for S. gracillimus over the whole study period. Examinations of stomachs showed that they probably died from starvation. Thus, S. gracillimus appears to have the least tolerance of food deprivation among the three species.

Table 1. The maximum length between capture points and home range area based upon the convex-polygon method for residents in Sorex unguiculatus, $S$. gracillimus, and $S$. caecutiens in the non-snow covered season in northern Hokkaido, 1988 and 1989. Results in parentheses are supplemental information for individuals that did not satisfy the conditions for the calculation of home range size. Y - young, OW overwintered (mature), M - male, F - female, UK - sex unknown.

\begin{tabular}{lcllcr}
\hline Species & No. & Age & Sex & Max. length $(\mathrm{m})$ & Area $\left(\mathrm{m}^{2}\right)$ \\
\hline S. unguiculatus & 002 & Y & UK & 36.5 & 175.0 \\
& 004 & OW $^{\mathrm{a}}$ & M & 36.2 & 295.6 \\
& 022 & OW & F & 15.0 & 37.5 \\
& $(033$ & Y & UK & 11.2 & - ) \\
& 035 & Y & UK & 36.3 & 499.0 \\
& 036 & Y & UK & 25.5 & 173.8 \\
& $(037$ & Y & UK & 20.0 & - ) \\
& 039 & Y & UK & 15.7 & 12.5 \\
S. gracillimus & 044 & Y & UK & 28.3 & 125.0 \\
& & & mean & 27.6 & 188.3 \\
& 020 & OW & M & 38.0 & 408.5 \\
& 026 & OW & M & 25.4 & 62.5 \\
S. caecutiens & $(027$ & OW & F & 15.8 & $25.0)$ \\
& $(053$ & Y & UK & 35.3 & $235.6)$ \\
& 061 & Y & UK & 42.5 & 298.2 \\
& & & mean & 35.3 & 259.4 \\
\hline
\end{tabular}

${ }^{a}$ Young in $1988,{ }^{b}$ Excluding the data in parentheses. 


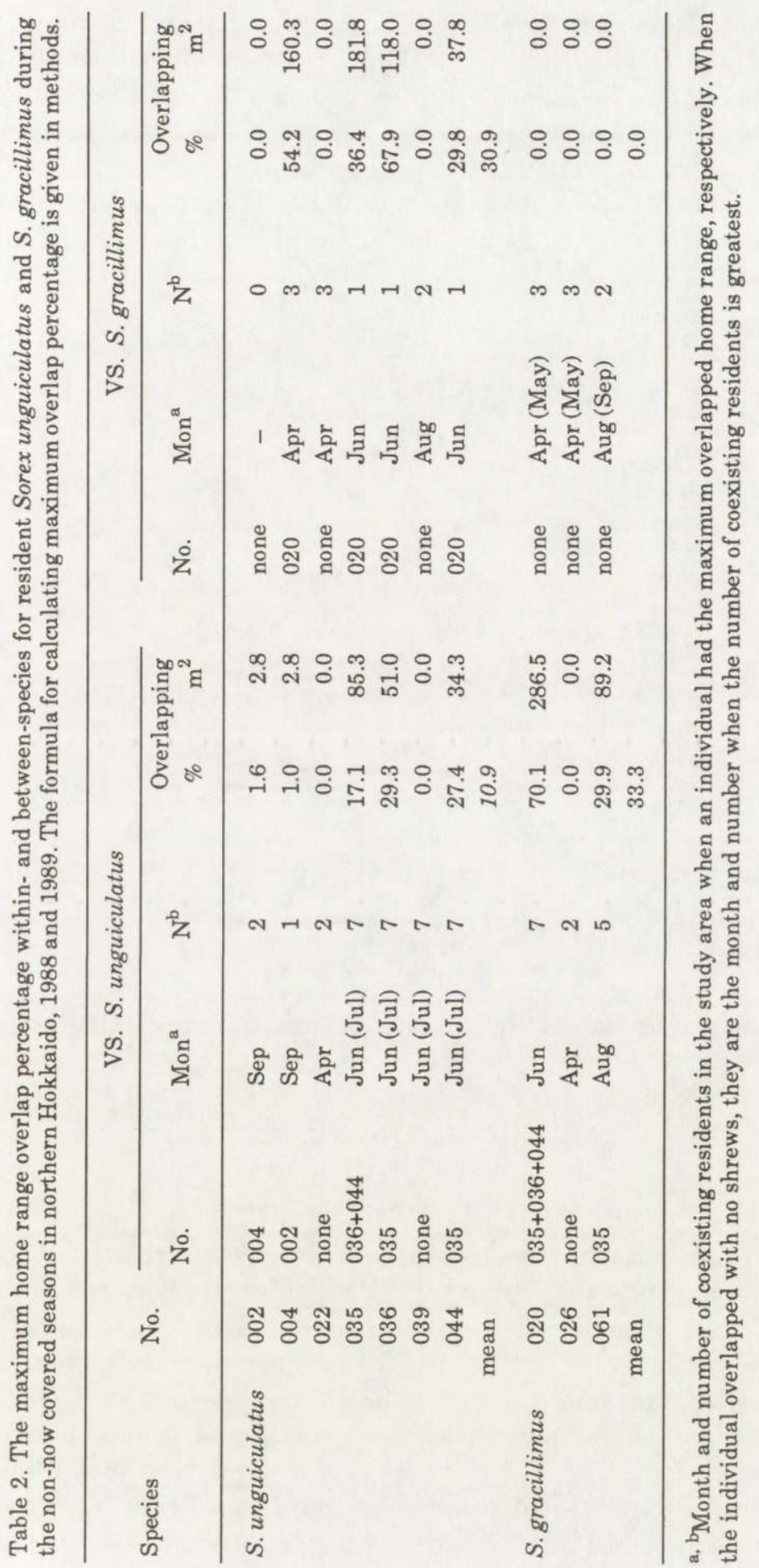


The mean home range size for $S$. grasillimus and $S$. unguiculatus was not significantly different $(U=5, p>0.05$ for the maximum length; $U=7, p>0.05$ for the area; two tailed Mann-Whitney's test), although the former species showed larger mean size (Table 1). No $S$. caecutiens statisfied the conditions for the calculation of home range size. S. unguiculatus and $S$. gracillimus had more exclusive home ranges within species than between species (Table 2), although statistical analysis (simulation analysis) could not be conduced due to insufficient sample size.
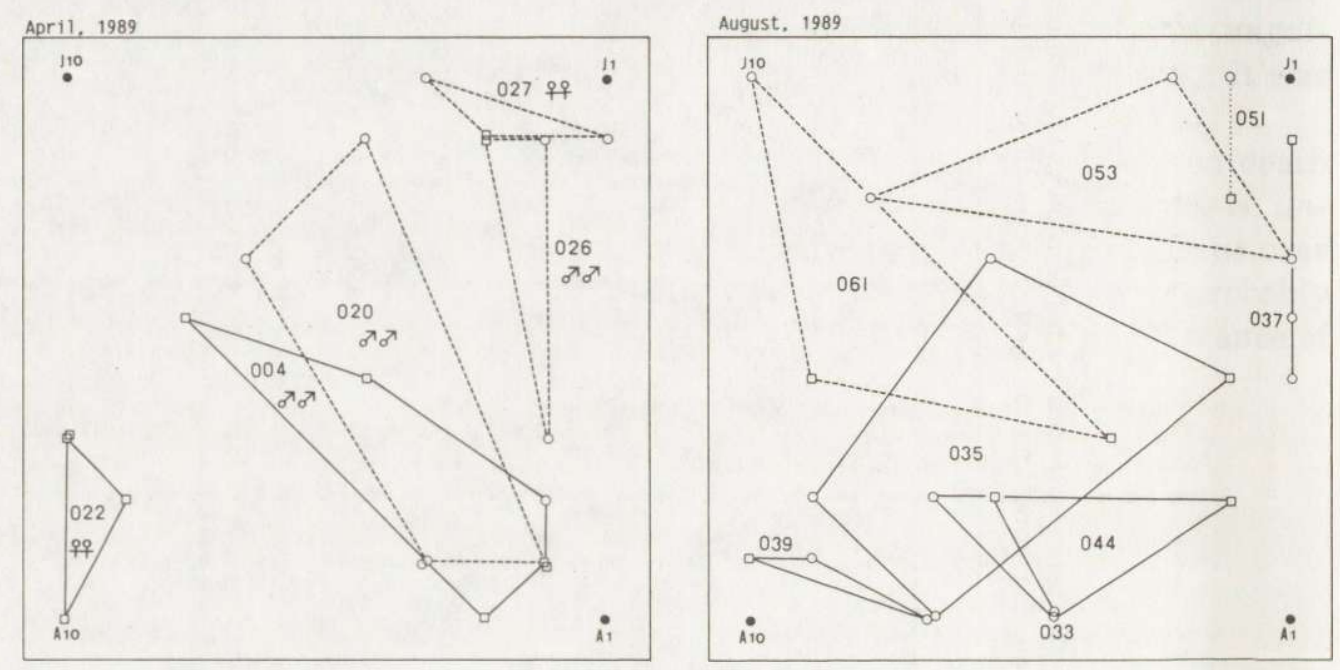

Fig. 2. Representative maps of shrews' home ranges in northern Hokkaido, Japan. Solid line - Sorex unguiculatus, broken line $-S$. gracillimus, dotted line $-S$. caecutiens. All capture points of each individual are used for drawing of the home range. Capture points are plotted with squares and circles; squares denote the capture points for the month in which home range of a shrew is drawn, and circles denote the points for the other months. Numbers within polygons are individual identification numbers of shrews.

\section{Discussion}

\section{Home range size}

Home range size of shrews was not positively related to body size among species. Home range size did not differ significantly between $S$. unguiculatus and $S$. gracillimus, although the former species has a much larger mean body size than the latter; e.g. mean body weight for overwintered males is $15.1 \mathrm{~g}(n=143)$ in S. unguiculatus, and $4.4 \mathrm{~g}(n=22)$ in $S$. gracillimus. I obtained no reliable information on home range size for S. caecutiens, whose mean body weight of overwintered males is $7.4 \mathrm{~g}(n=70)$. Instead, the mean home range size of $S$. caecutiens in central Hokkaido is $225.0 \mathrm{~m}^{2}(n=3)$ (K. Maekawa, pers. comm.), which is intermediate between the values for $S$. unguiculatus and $S$. gracillimus 
in the present study (Table 1). However, more samples are necessary to confirm the relationship between body mass and home range size for the shrews in Hokkaido.

Negative relationships between home range and body sizes have been reported for some sympatric shrews in Europe and North America, and the difference in home range size seems to be related to shrews' foraging behaviour and energy requirements. $S$. araneus has a smaller home range than the smaller $S$. minutus in Europe (Croin-Michielsen 1966, Dickman 1988, Shillito 1963), and Blarina brevicauda has a smaller home range than the smaller $S$. cinereus and $S$. arcticus in North America (Buckner 1957, 1966). The large species (S. araneus and $B$. brevicauda) are semi-fossorial foragers and feed heavily on earthworms, whereas the smaller ones (S. minutus, $S$. cinereus, and $S$. arcticus) are epigeal foragers and prey mainly on small terrestrial invertebrates (Aitchison 1987a, Babcock 1914, Butterfield et al. 1981, Churchfield 1980, 1982; Dickman 1988, Ellenbroek 1980, Ellenbroek and Hamburger 1991, Grainger and Fairley 1978, Michielsen 1966, Pernetta 1976a, Rudge 1968, Hamilton 1930, Whitaker and Mumford 1972). Generally speaking, costs of foraging are higher in burrowing species than wandering species (e.g. Vleck 1979), and therefore a burrower should not have a large foraging range if the cost is higher than energy gain per unit surface area. Furthermore, smaller shrews have higher energy requirements per unit body mass than larger ones (Aitchison 1987b, Genoud 1988, Pernetta 1976b). This suggests that the smaller species have to search for food more frequently if habitat quality is same for both species, or over larger areas if habitat quality is lower for the smaller species (e.g. Dill 1978, McNab 1963, Schoener 1983b, Simon 1975). Additionally, in Hokkaido, S. unguiculatus is regarded as a semi-fossorial forager, while $S$. gracillimus and $S$. caecutiens are regarded as epigeal foragers (Ohdachi 1990, Yoshino and Abe 1984), and the difference of home range size among these species might be explained by their foraging habits and body mass as in European and North American shrews.

\section{Home range overlap}

$S$. gracillimus showed exclusive home ranges or territories within species. In general, soricine shrews, except Cryptotis parva (Mock 1982), have exclusive territories within species; e.g. S. araneus and S. minutus (Buckner 1969, CroinMichielsen 1966, Ellenbroek 1980, Pernetta 1977, Shillito 1963), S. vagrans and S. obscurs (Hawes 1977, Ingles 1961), S. cinereus and S. arcticus (Buckner 1966), S. unguiculatus (female-female overlap; Inoue 1988, 1989), and B. brevicauda (Platt 1976). S. gracillimus in northern Hokkaido followed this general pattern of apparent intraspecific territoriality; data for S. caecutiens were too few to analyze.

Territoriality of shrews is generally maintained by direct fighting and odor marking (Crowcroft 1957, Dickman 1991, Hawes 1976, Platt 1976). In the present study, I sometimes found that two $S$. unguiculatus in the same traps were aggressive to one another, suggesting that the territoriality for this species is also 
maintained by aggressive behavior. In addition, it might be warthy to note that two $S$. gracillimus (male No. 026 and female No. 0.27 ) which had exclusive home ranges were trying to copulate in a trap (I-3) on April 27, 1989.

Four out of seven $S$. unguiculatus showed exclusive intraspecific home ranges but the remaining three had considerable overlap with conspecific individuals (Table 2). Thus, mean overlaps of $S$. unguiculatus in the present study was greater than that of other shrews mentioned earlier (Buckner 1966, 1969; CroinMichielsen 1966, Ellenbroek 1980, Hawes 1977, Ingles 1961, Inoue 1988, 1989; Pernetta 1977, Platt 1976, Shillito 1963). Inoue (1989) reported that home range overlap of $S$. unguiculatus was considerably great, as in the present study, between male individuals although females had strictly exclusive home ranges each other. Therefore, the large overlaps in the present study might be those between male individuals.

I obtained no information on the home range relationships between $S$. caecutiens and the other two Sorex species in the present study. However, one $S$. unguiculatus has been observed to overlap with the home ranges of three $S$. caecutiens in central Hokkaido (K. Maekawa, pers. comm.), suggesting that $S$. caecutiens also has tolerance of home range overlap with $S$. unguiculatus.

The overlap of home ranges is probably related to interspecific differences in diets and foraging habits. The main foods of $S$. unguiculatus are earthworms whereas those of $S$. gracillimus and $S$. caecutiens are small terrestrial invertebrates (Abe 1968, Inoue 1983, Inoue and Maekawa 1990, Ohdachi 1990). Therefore, interspecific competition for food might be higher within species than between $S$. unguiculatus and either $S$. gracillimus or $S$. caecutiens.

In other guilds of soricine shrews, interspecific differences in spacing may also be related to food habits. Two interspecific spacing relationships are known in shrew guilds. In one, territories overlap between species, as in $S$. araneus and S. minutus (Croin-Michielsen 1966, Pernetta 1977, Ellenbroek 1980) the other involves interspecific territoriality, as in $S$. cinereus and $S$. vagrans (Spencer and Pettus 1966) and S. vagrans and S. obscurus (Hawes 1977). S. araneus mainly eats earthworms whereas $S$. minutus eats small epigeal invertebrates, which they obtain from different vertical strata (Butterfield et al. 1981, Churchfield 1980, 1982; Croin-Michielsen 1966, Ellenbroek 1980, Grainger and Fairley 1978, Pernetta 1976a, 1977; Rudge 1968). On the other hand, the principal foods of $S$. cinereus and $S$. vagrans are the same small invertebrates (Buckner 1966, Clothier 1955, Hamilton 1930, Whitaker and Mumford 1972), and S. vagrans and S. obscurus also have similar life history patterns (Hawes 1977).

There is no information on the spacing relationships between $S$. gracillimus and $S$. caecutiens in Hokkaido. However, inferring from the other shrew guilds mentioned above, we can predict that $S$. gracillimus and $S$. caecutiens will show interspecific territoriality as in S. cinereus/S. vagrans and S. vagrans/S. obscurus, because the two species in Hokkaido consume similar food items (Ohdachi 1990) and thus may compete for food resources. Furthermore, S. gracillimus and 
$S$. caecutiens do not co-occur as the dominant and the second most dominant shrew species in various habitats and regions in Hokkaido (Ohdachi and Maekawa 1990a), suggesting that they compete more severely than either does with S. unguiculatus. This finding also suggests that they may have exclusive territories.

Acknowledgements: I thank K. Maekawa for providing his unpublished data and $\mathrm{H}$. Mori and $\mathrm{H}$. Abe for their academic and technical advice for this study. K. Sasa, T. Aoi, staff of Teshio Experimential Forest, Hokkaido University, and students of Institute of Applied Zoology, Hokkaido University supported my field work. B. Rathcke and C. Dickman commented critically on the earlier draft. I express my gratitude to them.

\section{References}

Abe H. 1958. Individual and age variations of two species of Sorex in Hokkaido. Mem. Facul. Agr., Hokkaido Univ. 3: 201 - 209. [In Japanese]

Abe H. 1967. Classification and biology Japanese Insectivora (Mammalia) I. Studied on variation and classification. J. Facul. Agr., Hokkaido Univ. 55: 191 - 269.

Abe H. 1968. Clasification and biology of Japanese Insectivora (Mammalia) II. Biological aspects. J. Facul. Agr., Hokkaido Univ. 55: 429 - 458.

Aitchison C. W. 1987a. Review of winter tropic relations of soricine shrews. Mammal. Rev. 17: 1-24.

Aitchison C. W. 1987b. Winter energy requirements of of soricine shrews. Mammal. Rev. 17: 25 - 38 .

Babcock H. L. 1914. Some observations on the food habits of the short-tailed shrew (Blarina brevicauda). Science 40: $526-530$.

Buckner C. H. 1957. Population studies on small mammals of southern Manitoba. J. Mammal. 38: $87-97$.

Buckner C. H. 1966. Populations and ecological relationships of shrews in tamarack bogs of southeastern Manitoba. J. Mammal. 47: 181 - 194.

Buckner C. H. 1969. Some aspects of the population ecology of the common shrew, Sorex araneus, near Oxford, England. J. Mammal. 50: 326 - 332.

Butterfield J., Coulson J. C. and Wanless S. 1981. Studies on the distribution, food, breeding biology and relaive abundance of the pygmy and common shrew (Sorex minutus and $S$. araneus) in upland areas of northern England. J. Zool., Lond. 195: 169 - 180.

Churchfield S. 1980. Subterranean foraging and burrowing activity of the common shrew. Acta theriol. 25: $451-459$.

Churchfield S. 1982. Food availability and the diet of the common shrew, Sorex araneus, in Britain. J. Anim. Eol. 51: $15-28$.

Clothier R. R. 1955. Contribution to the life history of Sorex vagrans in Manitoba. J. Mammal. 36: $214-22$ t.

Connel J. H 1983. On the prevalance and relative imortance of interspecific competition: evidence from fiell experiments. Amer. Nat. 122: $661-696$.

Croin-Michidsen N. 1966. Intraspecific and interspecific competition in the Sorex araneus L. and S. minutıs L. Archs. Néerl. Zool. 17: $73-174$.

Crowcroft P.1957. The life of the shrew. Max Reinhardt. London: $1-166$.

Dickman C. R. 1988. Body size, prey size, and community structure in insectivorous mammals. Ecology 69: $569-580$.

Dickman C.R. 1991. Mechanisms of competition among insectivorous mammals. Oecologia 85: $464-47$.

Dill L. M. 1778. An energy based model of optimal feeding-territory size. Theoret. popul. Biol. 14: $369-42$ ? 
Ellenbroek F. J. M. 1980. Interspecific competition in the shrews Sorex araneus and $S$. minutus (Soricidae, Insectivora); a population study of the Irish pygmy shrew. J. Zool., Lond. 192: $119-136$.

Ellenbroek F. J. M. and Hamburger J. 1991. Interspecific interactions between the shrews Sorex araneus L. and S. minutus L. (Soricidae, Insectivora) and the use of habitat: a laboratory study. Netherlands J. Zool. 41: $32-62$.

Genoud M. 1988. Energetic strategies of shrews: ecological constraints and evolutionary implications. Mammal. Rev. 18: 173 - 193.

Grainger J. P. and Fairley J. S. 1978. Study on the biology of the pygmy shrew Sorex minutus in the west of Ireland. J. Zool., Lond. 186: $109-141$.

Hawes M. L. 1976. Odor as a possible isolating mechanism in sympatric species of shrews (Sorex vagrans and $S$. obscurus). J. Mammal. 58: $354-367$.

Hawes M. L. 1977. Home range, territoriality, and ecological separation in sympatric shrews, Sorex vagrans and $S$. obscurus. J. Mammal. 58: $354-367$.

Hamilton W. J. Jr. 1930. The food of soricidae. J. Mammal. 11: 26 - 39.

Hill B. G. and Lein M. R. 1989. Territory overlap and habitat use of sympatric chickadees. Auk 106: $259-268$.

Ingles L. G. 1961. Home range and habitats of the wandering shrew. J. Mammal. 42: 455 - 462.

Inoue T. 1983. Life history of Sorex unguiculatus Dobson. M. S. thesis, Hokkaido Univ., Sapporo: 1 - 48. [In Japanese]

Inoue T. 1988. Territory establishment of young big-clawed shrew, Sorex unguiculatus (Dobson) (Insectivora, Soricidae). Res. Popul. Ecol. 30: 83 - 93.

Inoue T. 1989. Social organization and life history of Sorex unguiculatus Dobson. Ph. D. dissertation, Hokkaido Univ., Sapporo: 1 - 120. [In Japanese]

Inoue T. and Maekawa K. 1990. Difference in diets between two species of soricine shrews, Sorex unguiculatus and S. caecutiens. Acta theriol. 35: $253-260$.

Macdonald D. 1984. The encyclopedia of mammals. Facts on File, New York: $1-895$.

McNab B. K. 1963. Bioenergetics and the determination of home range size. Amer. Nat. 97: 133 - 140.

Mock O. B. 1982. The least shrew (Cryptotis parva) as a laboratory animal. Lab. anim. Sci. 32: $177-179$

Murray B. G. Jr. 1971. The ecological consequences of interspecific territorial behavior in birds. Ecology 52: $414-423$.

Ohdachi S. 1990. Comparative ecology on three species of Sorex, S. unguiculatus, S. gracillimus, and S. caecutiens, during the non-snow covered seasons in northern Hokkaido. M. S. thesis, Hokkaido Univ., Sapporo: 1 - 99. [In Japanese]

Ohdachi S. and Maekawa K. 1990a. Geographic distribution and relative abundance of four species of soricine shrews in Hokkaido, Japan. Acta theriol. 35: 261 - 267.

Ohdachi S. and Maekawa K. 1990b. Relative age, body weight, and reproductive condition in three species of Sorex (Soricidae, Mammalia) in Hokkaido. Res. Bull. College. Exp. For., Facul. Agr., Hokkaido Univ. 47: 535 - 546.

Pernetta J. C. 1976a. Diets of the shrew Sorex araneus L. and S. minutus L. in Wytham grassland. J. Anim. Ecol. 45: 899 - 912.

Pernetta J. C. 1976b. Bioenergetics of British shrews in grassland. Acta theriol. 21: $481-497$.

Pernetta J. C. 1977. Population ecology of British shrews in grassland. Acta theriol. 22: 279 - 296.

Platt W. J. 1976. The social organization and territoriality of a short-tailed shrew (Blarina brevicauda) population in old-field. Anim. Behav. 24: 305 - 318.

Rudge M. R. 1968. The food of the common shrew Sorex araneus L. (Insectivora: Soricidae) in Britain. J. Anim. Ecol. 37: 565 - 581.

Schoener T. W. 1968. The Anolis lizards of Bimini: resource partitioning in a complex fauna. Ecology 49: $704-726$.

Schoener T. W. 1983a. Field experiments in interspecific competition. Amer. Nat. 122: 240 - 285. 
Schoener T. W. 1983b. Simple models of optimal feeding-territory size: a reconciliation. Amer. Nat. 121: $608-629$.

Schoener T. W. 1986. Resource partitioning. [In: Community ecology: pattern and process. J. Kikkawa and D. J. Anderson, eds]. Blackwell Scientific Publications, London: 91 - 119.

Shillito J. F. 1963. Observations on the range and movements of a woodland population of the common shrew Sorex araneus L. Proc. zool. Soc. London 140: 533 - 546.

Simon C. A. 1975. The influence of food abundance on territory size in the iguanid lizard Sceloporus jarrovi. Ecology 56: $993-998$.

Spencer A. W. and Pettus D. 1966. Habitat preferences of five species of long-tailed shrew. Ecology 47: $677-683$.

Stickel L. F. 1954. A comparison of certain methods of measuring ranges of small mammals. J. Mammal. 35: $37-47$.

Vleck D. 1979. The energy cost of burrowing by the pocket gopher Thomomys bottae. Physiol. Zool. 52: $122-136$.

Wiens J. A. 1989. The ecology of bird communities. Volume 1. Fundation and patterns. Cambridge University Press, Cambridge: 1 - 539.

Whitaker J. O. Jr. and Mumford R. E. 1972. Food and ectoparasites of Indiana shrews. J. Mammal. 53: $329-335$.

Yoshino H. and Abe H. 1984. Comparative study on the foraging habits of two species of soricine shrews. Acta theriol. 29: $35-43$.

Received 18 December 1991, accepted 22 May 1992. 